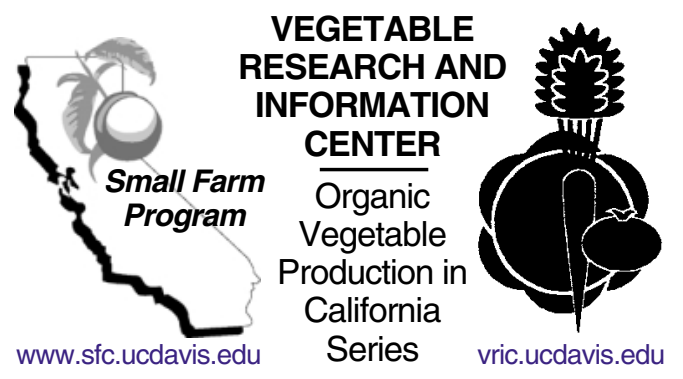

\title{
PLANT DISEASE MANAGEMENT FOR ORGANIC CROPS
}

\author{
STEVEN T. KOIKE, UC Cooperative Extension Farm Advisor, \\ Monterey and Santa Cruz Counties; MARK GASKELL, UCCE \\ Farm Advisor, Santa Barbara and San Luis Obispo Counties; \\ CALVIN FOUCHE, UCCE Farm Advisor, San Joaquin County; \\ RICHARD SMITH, UCCE Farm Advisor, Monterey and \\ Santa Cruz Counties; and JEFF MITCHELL, UCCE Vegetable \\ Crops Specialist, Kearney Agricultural Center, Parlier
}

Specific information on organic vegetable production practices in California is scarce, and growers need sound information to guide their management decisions. The Organic Vegetable Production in California Series is made up of publications written by Farm Advisors and Specialists from the University of California's Division of Agriculture and Natural Resources. Each publication addresses a key aspect of organic production practices applicable to all vegetable crops.

Plant diseases create challenging problems in commercial agriculture and pose real economic threats to both conventional and organic farming systems. Plant pathogens are difficult to manage for several reasons. First of all, plant pathogens are hard to identify because they are so small. The positive identification of a pathogen often requires specialized equipment and training, and in some cases accurate diagnosis in the field is difficult.

Plant pathogens are constantly changing and mutating, resulting in new strains and new challenges to growers. Also, given the local, regional, and international movement of seed, plant material, and farming equipment, new and introduced pathogens periodically enter the California system to cause new disease problems.

Disease management is complicated by the presence of multiple types of pathogens. For any one crop the grower must deal with a variety of fungi, bacteria, viruses, and nematodes. This situation is even more complicated for organic vegetable growers because they usually produce a wide array of vegetable crops and are prohibited from applying conventional synthetic fungicides. The world market continues to be extremely competitive and continues to require that growers supply high-quality, disease-free produce with an acceptable shelf life. Disease management is therefore a critical consideration in organic vegetable production.

In an organic system, it is appropriate to develop disease-control strategies that have an ecological basis. For example, insofar as possible the organic system should encourage the growth and diversity of soilinhabiting and epiphytic (plant surface dwelling) microorganisms that have the potential to exert beneficial and pathogen-antagonistic influences. An increase in the genetic diversity of the crop host rotation is another management step that incorporates ecological considerations. The integration of disease management decisions with insect and weed control and general production practices is another step consistent with this approach.

\section{RESISTANT PLANTS AND CULTIVARS}

One of the most important components in an integrated disease control program is the selection and planting of cultivars that are resistant to pathogens. The term resistance usually describes the plant host's ability to suppress or retard the activity and progress of a pathogenic agent, which results in the absence or reduction of symptoms. However, it is important to clearly establish a common definition of the term when discussing this quality with individuals from different sectors of the agricultural industry. Growers, researchers, plant breeders, and seed sellers may have slightly different understandings of the term. In addition, the word tolerance, which has a slightly different meaning, is sometimes used interchangeably with resistance, resulting in some confusion. By definition, tolerant plants can endure severe disease without suffering significant losses in quality or yield; however, these tolerant plants do not significantly inhibit the pathogen's activity, and disease symptoms may be clearly evident. Resistant plants usually suppress the pathogen in some fashion.

There are some distinct advantages to planting disease-resistant plant cultivars. Such selections are completely non-disruptive to the environment, and in fact their use enables growers to reduce and in some cases eliminate the application of chemicals used for pathogen control. The use of cultivars resistant to one disease is compatible with disease management steps taken to control other diseases. A final advantage is that for some host-pathogen systems the stability of the 
resistance is long lasting and the cultivars can remain resistant for many years.

There are some disadvantages to the use of resistant cultivars. The greatest shortcoming is that resistance is not available for all diseases on all crops. For several of the most damaging plant diseases, such as tomato late blight (Phytophthora infestans) and white rot (Sclerotium cepivorum) of Alliums, acceptable no resistant cultivars are yet available. In addition, commercial seed companies and plant breeders rarely invest in efforts to develop resistant cultivars for specialty or minor crops. Hence there will be specialty commodities, many of which are popular choices for organic producers, that will continue to lack resistance to their disease problems. Even if resistant varieties are being developed, the long development time and high market demand for resistant cultivars will result in expensive seed, and that will affect farmer budgets.

Another shortcoming of some resistant cultivars is that some of these selections lack adequate horticultural characteristics in regard to appearance, quality, color, yield, and other important criteria. Celery resistant to Fusarium oxysporum f. sp. apii may not succumb to this Fusarium yellows fungus, but it may also be unacceptably ribby, short, or low-yielding. A cultivar that is resistant to one disease may be quite susceptible to another important disease or insect pest. A lettuce cultivar that is resistant to lettuce mosaic virus may be quite sensitive to corky root disease (caused by Rhizomonas suberifaciens); a lettuce selection that resists corky root may be very susceptible to downy mildew (Bremia lactucae). A final disadvantage to resistance is that, depending on the hostpathogen system, resistance is not long-lasting and new strains of the pathogen readily develop, making the crop susceptible once again.

Depending on the particular disease involved, the failure of plant resistance can be either a rare or a regular event. In most cases, resistance failure is attributed to the development of new strains of the target pathogen that overcome the resistance genes of the previously resistant cultivar. The downy mildew disease of spinach provides a good case study of this phenomenon. During the past 50 years in California, a new race of the spinach downy mildew fungus (Peronospora farinosa f. sp. spinaciae) would periodically occur in the state, causing significant damage to the previously resistant spinach cultivars. Plant breeders would counter with new cultivars with genes resistant to the new race. Growers would then enjoy several years of mildew-free spinach until yet another race developed. This back-and-forth dynamic has occurred for every one of the six races of the disease that have been confirmed in California.

Despite the challenges of developing resistant cultivars and the setbacks of resistance breakdown, resistant plants remain among the most important weapons for disease control in organic systems. Organic growers are encouraged to actively and thoroughly investigate which resistant cultivars are available and to test to determine which cultivars perform best under their particular growing conditions.

\section{SITE SELECTION}

Before planting crops, a grower should carefully plan out planting and crop rotation strategies to avoid insofar as possible any known problem areas. A grower can incur significant losses if he or she plants susceptible crops in a field known to be infested with persistent soilborne pathogens. Plant-pathogenic fungi such as Armillaria, Fusarium (the wilt-causing species), Plasmodiophora, Sclerotium, and Verticillium are true soil inhabitants and will persist in soil for many years, even in the absence of a plant host. Because not all fields are infested with these fungi, the grower is advised to select a planting site away from such fields. Soilborne fungi such as Phytophthora, Pythium, and Rhizoctonia often are much more widespread, so site selection might be less of an option in avoiding these organisms.

There are also other planting situations that create risks that should be avoided. Pastures, foothills, riverbanks, grasslands, and other areas that support weeds and natural vegetation often are reservoirs of pathogens that cause virus and viruslike diseases. The vectors that carry such pathogens also can be found in these high-risk areas and often migrate into production fields. For example, the aster yellows phytoplasma and its leafhopper vector can be found in weedy grasslands in coastal California. Once the grassland vegetation dries up in the summer, the leafhoppers migrate into nearby lettuce or celery fields, resulting in aster yellows disease in these fields.

Consider pertinent environmental factors when selecting a planting site. Crops planted very close to the seacoast tend to be more at risk from downy mildew diseases as a result of the increased and persistent humidity. Just a few miles inland from the ocean, however, humidity can be significantly lower, decreasing the disease pressure for downy mildew. An understanding of soil factors is critical in avoiding some root and crown diseases. A site that has well-drained, sandy soil reduces the risk of damping-off and root rot for sensitive crops such as spinach.

For any site selection decision, careful and detailed record keeping is essential. As a grower, you should keep notes on previous soilborne disease problems associated with certain fields, the position of fields in relation to other key areas (weed reservoirs), the environmental characteristics of importance for each loca- 
tion, and the nature of soil, water, and other physical features of each site.

\section{EXCLUSION}

The practice of keeping out any materials or objects that are contaminated with pathogens or diseased plants and preventing them from entering the production system is known as exclusion. For some diseases, seedborne pathogens are a primary means of pathogen dissemination. Growers should purchase seed that has been tested and certified to be below a certain threshold infestation level or that has been treated to reduce pathogen infestation levels. Note that the designation "pathogenfree seed" really is not a valid term because it is not possible to know whether a seed lot is, in its entirety, absolutely free of all pathogens. Seed tests only examine representative samples, but in most cases the tests are accurate enough to give a true picture of the risk of diseases initiated by seedborne pathogens. If a grower produces or purchases transplants, they too should be as free as possible of pathogen contamination (where the pathogen is present on the plant but has not yet caused visible symptoms) and from disease (where symptoms are actually visible).

For greenhouse crop production or the production of transplants, all materials should be clean and free of pathogens. By using clean or new pots, trays, and soilless potting mix, a grower can prevent the introduction of soilborne pathogens into the greenhouse system. The recycling of potting mixes is strongly discouraged, and pots and trays should be reused only if they are properly cleaned with steam, bleach, or other disinfectants.

Soil and water can harbor pathogens as well. Take care to see that no infested soil or water is introduced into uninfested areas. Tomato bushy stunt virus of lettuce, tomato, and other crops is found in river, flood, and runoff waters. Growers who have dredged up soil from ditches and dispersed it onto fields have found that their fields can become infested with the virus and subsequent plantings can be severely diseased. Water draining from fields can carry a number of pathogens, and growers should not recycle or reuse it without carefully considering potential risks and then taking appropriate safety precautions. Soil adhering to tractor equipment and implements can spread soilborne pathogens from infested fields into clean fields. It is a good idea to reduce the off-site movement of these infested materials as much as possible.

\section{APPLYING CONTROL MATERIALS}

Once vegetable crops are in the field or greenhouse, it will sometimes be necessary to apply some sort of pro- tectant or eradicant spray or dust material for disease control, if one is available. Unfortunately, the selection of effective, proven materials approved for organic use is limited.

Inorganic disease control materials, primarily copper- and sulfur-based fungicides, have been used for centuries. These inorganics are generally inexpensive and widely available, and they constitute minimal threats to the environment. However, their efficacy for disease control varies. While protectant copper fungicides have some activity against a wide range of fungal and bacterial pathogens, they are not extremely effective, and sole reliance upon them probably will not result in excellent disease control. Sulfurs also exhibit some activity against many pathogens, but they usually provide excellent control against only certain pathogens, such as powdery mildew fungi. Both coppers and sulfurs can burn sensitive vegetable crops under some environmental conditions.

Oils, plant extracts, and other natural plant products are being investigated for use as disease-control sprays. Such products should be compatible with organic production practices, but reliable disease control has yet to be demonstrated.

Bicarbonate-based fungicides have recently become available for control of plant diseases. Bicarbonates have demonstrated acceptable activity against powdery mildew and a few other diseases. It is not known, however, whether bicarbonates alone will provide seasonlong protection for an organically grown crop.

Disease control using microorganisms (biocontrol) or chemical by-products made by microorganisms is generating a good deal of interest. However, the history of successful biological control of plant diseases is not encouraging. Very few effective, economically feasible biological control materials are commercially available. Much research and development remains to be done.

For the best results possible with any of these materials, appropriate application technique (proper equipment, spray volume, and plant coverage) and timing are essential. Most materials do not perform well if the disease is established, so applications should be made prior to extensive infection. Before applying a product, a grower should confirm that the material is approved for use in organic production. Consult product labels, UC Cooperative Extension farm advisors, pest control advisers, and your local Agricultural Commissioner's Office for product use information and restrictions.

\section{CULTURAL PRACTICES}

There are a number of cultural practices that a grower should consider when designing an integrated disease control system. As a general approach, growers should 
take steps to grow vigorous, high-quality plants using the best farming practices possible. Listed below are some specific cultural practices that can help to manage diseases.

Crop rotation is an important consideration in disease management. Rotation using diverse crops, inclusion of cover crops, and appropriate use of fallow (hostfree) periods all can contribute to the reduction of inoculum levels for soilborne pathogens and the increase of diversity in soil microflora. In contrast, consecutive plantings of the same crop in the same field often lead to increases in soilborne pathogens. Too little crop rotation in a given area can also simulate a monoculture effect that might increase foliar diseases.

Recent research has shown that certain plants, besides being revenue-generating crops, also have a suppressive effect on diseases. For example, after broccoli and other crucifer crops are harvested and the plant residue is plowed into the soil, the decomposition of the broccoli stems and leaves releases natural chemicals that can significantly reduce the number of Verticillium dahliae microsclerotia. This broccoli effect can be an important consideration in crop rotation strategies. Some cover crops (mustards, sudangrass) might also share this beneficial effect and could be considered in the crop rotation scheme. It is important to remember that while rotations with non-susceptible plants and cover crops may help reduce soilborne pathogen numbers, significant decreases in such populations are likely to take many seasons.

When devising a crop rotation strategy, a grower should also be aware of which crops and cover crops might increase disease problems. A vetch cover crop, if planted into a field with a history of lettuce drop, can greatly increase the number of infective sclerotia of Sclerotinia minor. Vetch is a known host of root-knot nematode (Meloidogyne species) and also might increase soil populations of Pythium and Rhizoctonia dampingoff fungi. While oilseed radish could be a potential trap crop for cyst nematode (Heterodera species), as a cover crop it is a host of root-knot nematode and the clubroot fungus (Plasmodiophora brassicae).

There are many factors to consider in regard to planting a crop. Timing can be an important question. If cauliflower is planted into Verticillium-infested fields in the spring or summer, it is likely to experience disease and possible crop loss. However, if cauliflower is planted into the same fields in the late fall or winter it will exhibit no Verticillium wilt symptoms, presumably because the soil temperatures are too cool to allow the fungus to develop and cause significant disease.

Disease can also be influenced by steps taken prior to and during the planting process. Tillage procedures should reduce plant residues left from previous crops.
Proper preparation of the field and the subsequent raised beds should reduce problems in areas that are subject to poor drainage, pooling of water, and other conditions that favor pathogens. Soil and bed preparation should result in good soil tilth so that seed or transplants are placed in a soil that favors plant development. Planting depth for seed or transplants should be tailored to enhance seed emergence or transplant establishment. Poor soil preparation can result in stressed and exposed plants and increased damping-off problems due to soil fungi.

Irrigation management is clearly an important factor when it comes to disease control. Regardless of the irrigation method a grower chooses (furrow, sprinkler, or drip), timing and duration of irrigations should satisfy crop water requirements without allowing for excess water. Overwatering greatly favors most soilborne pathogenic fungi. For most foliar diseases, overhead sprinkler irrigation enhances pathogen survival and dispersal and disease development. Bacterial foliar diseases are particularly dependent upon rain and sprinkler irrigation. A grower should consider limiting or eliminating sprinkler irrigation if foliar diseases are problematic for a specific crop or field.

The selection and application of fertilizers, in a few documented situations, can significantly influence disease development. For example, the use of the nitrate form of nitrogenous fertilizers can increase the severity of lettuce corky root disease. The excessive use of nitrogen fertilizers can result in leaf growth that is overly succulent and more susceptible to some diseases. On the other hand, liming the soil to raise $\mathrm{pH}$ levels can reduce symptom expression for clubroot disease of crucifers. In general, however, fertilizer management is not directly related to disease control.

Field sanitation is the removal or destruction of diseased plant residues. In some field situations, sanitation is an appropriate step for managing diseases. Once lettuce has been harvested, for example, the remaining plants can act as a reservoir for lettuce mosaic virus. Sanitation in this case would include plowing down the old plants. Lettuce drop, caused by the fungus Sclerotinia minor, occurs when sclerotia develop on lettuce plant residues and remain in the top few inches of soil. One form of sanitation involves deep plowing in which moldboard plows invert the soil and bury sclerotia. Note that this procedure is effective only if sclerotia are low to moderate in number.

Sanitation measures are more commonly applied in greenhouse situations. The removal of dead or dying transplants can help reduce inoculum that could otherwise spread to adjacent transplants. The removal of senescent tomato or cucumber plants might reduce 
(though not prevent) the spread of Botrytis spores. Roguing is a special form of plant sanitation that involves the physical removal of diseased plants from the field. While not applicable in many situations, researchers have shown that for sclerotia-forming fungi (such as Sclerotinia minor on lettuce) the regular removal of diseased plants can gradually reduce the overall number of sclerotia in fields.

The management of other pests is a cultural control that could greatly influence the development of plant diseases. In particular, virus disease management is more effective when weeds and insects are also controlled. Weeds are known reservoirs of a number of viral and bacterial pathogens.

Soil solarization is the use of plastic tarps placed on the soil surface to increase soil temperatures to a level that kills soilborne pathogens, weeds, and other crop pests. Soil solarization works best in areas with acceptably high summer temperatures. These temperatures generally do not occur in California's coastal regions. Soil solarization will not eradicate a pathogen from a field, but it may lower pathogen populations. Soil flooding is a related though seldom-used means of creating conditions-in this case, saturated soil over an extended period - that might result in a decline of soilborne pathogens.

Finally, the ability to manipulate environmental conditions in a greenhouse vegetable transplant or production system can be used to help control diseases. Botrytis diseases can be better managed if warm, humid air is vented out of the greenhouse. Because rain is not a factor in greenhouses, many bacterial foliar diseases can be virtually eliminated if drip irrigation or sub-irrigation systems are used.

\section{COMPOSTS}

Incorporation of composts into soils is a fundamental cultural practice in organic production. Composts benefit the soil's fertility and condition in a number of ways, and also undoubtedly benefit disease management in some way. However, research studies and empirical data that clearly document any disease control benefits resulting from field-application of compost are lacking. Despite this lack of information on disease control, composts should be added to farmed soils in order to increase soil microflora diversity and populations.

\section{PLANT DISEASE DIAGNOSTICS}

The first step in any management decision regarding disease control is to determine which diseases and pathogens are causing the problem. Accurate and timely diagnosis of plant diseases is an essential component of integrated disease control in organic and conventional systems. Disease diagnosis is enhanced when all professionals, including the grower, field personnel, pest control advisor, consultant, and extension personnel, work together to ascertain the cause of the problem. Often, field identification is impossible and samples must be submitted to a qualified laboratory for analysis.

Once a diagnosis has been determined, growers and other decision makers can settle on appropriate steps to take to manage the problem. Again, detailed record keeping will help the grower deal with the current problem and at the same time provide a database from which the grower can plan disease management steps for future crops.

For assistance with plant disease diagnosis, contact your pest control advisor, local Cooperative Extension Farm Advisor, or other professionals trained in plant pathology, pest management, or plant production. 


\section{OTHER PUBLICATIONS IN THIS SERIES}

Organic Certification, Farm Production Planning, and Marketing, UC ANR Publication 7247

Soil Management and Soil Quality for Organic Crops, UC ANR Publication 7248

Soil Fertility Management for Organic Crops, UC ANR Publication 7249

Weed Management for Organic Crops, UC ANR Publication 7250

Insect Pest Management for Organic Crops, UC ANR Publication 7251

\section{REFERENCES}

Integrated Pest Management series. University of California Statewide Integrated Pest Management Project (available through UC ANR Communication Services)

Soil Solarization: A Nonpesticidal Method for Controlling Diseases, Nematodes, and Weeds. UC ANR Publication 21377

UC IPM Pest Management Guidelines. UC ANR Publication 3339

An electronic version of this publication is available on the University of California ANR Communication Services website at http:/ / anrcatalog.ucdavis.edu.

Publication 7252

(C) 2000 by the Regents of the University of California,

Division of Agriculture and Natural Resources. All rights reserved.

The University of California prohibits discrimination against or harassment of any person employed by or seeking employment with the University on the basis of race, color, national origin, religion, sex, physical or mental disability, medical condition (cancer-related or genetic characteristics), ancestry, marital status, age, sexual orientation, citizenship, or status as a covered veteran (special disabled veteran, Vietnam-era veteran or any other veteran who served on active duty during a war or in a campaign or expedition for which a campaign badge has been authorized).

University Policy is intended to be consistent with the provisions of applicable State and Federal laws.

Inquiries regarding the University's nondiscrimination policies may be directed to the Affirmative Action/Staff Personnel Services Director, University of California, Agriculture and Natural Resources, 1111 Franklin, 6th Floor, Oakland, CA 94607-5200 (510) 987-0096. 